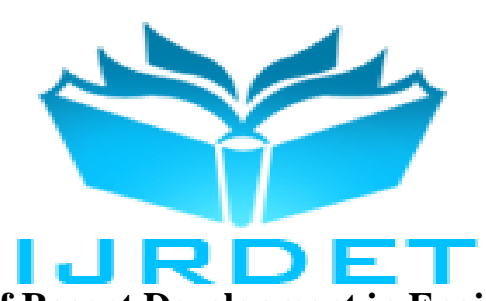

International Journal of Recent Development in Engineering and Technology

Website: www.ijrdet.com (ISSN 2347 - 6435 (Online) Volume 10, Issue 1, June 2021)

Manuscript Received: 12 Feb 2021, Received in Revised Form: 14 May 2021, Accepted: 20 June 2021 DOI: 10.54380/IJRDETV10I104

\title{
Evaluation of the Performance of Cryogenically Treated Carbide İnserts in the Turning of AISI 1040 Steel
}

\author{
Adnan Calik ${ }^{1}$, Nazmiye Onac ${ }^{2}$, Busra Komur ${ }^{3}$, Nazim Ucar $^{4}$ \\ ${ }^{1,2,3}$ Department of Machine and Manufacturing, Isparta University of Applied Sciences, Isparta, Turkey \\ ${ }^{4}$ Physics Department, Faculty of Arts and Sciences, Suleyman Demirel University, Isparta, Turkey \\ ${ }^{1}$ adnancalikesdu.edu.tr, ${ }^{2}$ nonacesdu.edu.tr, ${ }^{3}$ bkomuresdu.edu.tr, ${ }^{4}$ nazimucaresdu.edu.tr
}

\begin{abstract}
In this study, the effects of cryogenic treatment on tool wear and surface roughness of tungsten carbide inserts coated with TiAlN were investigated as a function of cutting speed and feed rate. It is observed that the surface roughness increases with increased cutting speed, feed rate and also applied cryogenic processing. In other words, the effect of feed rate and cutting speed is very high on the surface roughness. On the other hand, the results showed that the cryogenic treatment is a non-effective process to enhance the wear resistance and tool life of inserts due to brittle region between coated layer and surface.
\end{abstract}

Keywords-- tungsten carbide; wear; cryogenic, treatment; tempering, inserts

\section{INTRODUCTION}

The wear performance and tool life of tool steels plays a major role in increasing productivity and consequently is an important economic factor [1]. Therefore, considerable effort is expended on the improvement of these properties of tool steels. Previous results have shown that tool wear can be reduced by selecting tool materials, coatings, or treatments [2-4]. Corresponding to this, it has been shown that using cryogenic treatment (CT) on these materials increases the wear strength, decrease the friction coefficient, and improve tool life [5-7]. Some literatures have also reported the influence of CT on residual stress, micro-structural evolution, tensile properties, fatigue properties and other mechanical properties of many kinds of metal materials $[8,9]$.

Tungsten carbide (WC) is a high performance material formed from tungsten and carbon $[10,11]$. The WC is primarily used in the production of a wide variety of industrial tools and wear parts that are subject to a great deal of stress. The studies reveal the contribution of CT in improving the properties of WCs.
Corresponding to this, Thakur et al.[12] confirmed a slight increase in the micro-hardness in WC tools due to $\mathrm{CT}$, which was due to formation of additional complex carbides such as Co6W6C or Co3W3C. In addition to this, the cryogenically treated $\mathrm{WC}$ is more wear resistance due to increase in the population density of carbides [13]. On the other hand, it has been noted that the CT of WC inserts improves tool life performance to a certain extent[14]. This is largely dependent on the machining conditions and the length of machining time.

The literature review reveals the contribution of CT in improving the properties of WCs, but the work does not adequately clarify the choice of the number of posttempering cycles during CT and behaviors of cutting tools made of WC. In this study, we intend to determine the influence of the cryogenic treatment on the wear performance and surface roughness of WC cutting tools as a function of machining parameter (cutting speed and feed rate). The efforts are made to understand the mechanism behind the change in wear characteristics and surface roughness due to $\mathrm{CT}$.

\section{EXPERIMENTAL METHOD}

In this study, the WC cutting tools of $0,4-0,8-1,6 \mathrm{~mm}$ nose radius, belonging to ISCAR companies were used in experiments. Firstly, the WC cutting tools were coated with TiAlN using Physical Vapor Deposition (PVD) method. After this process, cryogenic transaction was applied where the part of the coated WC cutting tools was gradually cooled from room temperature to $-145^{\circ} \mathrm{C}$ with a cooling rate of about $1-2^{\circ} \mathrm{C} / \mathrm{min}$ and after 24 hours at this temperature, it was gradually warmed to room temperature with a heating rate of $1-2{ }^{\circ} \mathrm{C} / \mathrm{min}$. After cryogenic treatment, the cutting tools were tempered at $200{ }^{\circ} \mathrm{C}$ for 2 hours. The schematic of cryogenic treatment processes and experimental conditions were shown Fig. 1 and Table 1, respectively. 
International Journal of Recent Development in Engineering and Technology Website: www.ijrdet.com (ISSN 2347 - 6435 (Online) Volume 10, Issue 1, June 2021)

Manuscript Received: 12 Feb 2021, Received in Revised Form: 14 May 2021, Accepted: 20 June 2021 DOI: 10.54380/IJRDETV10I104

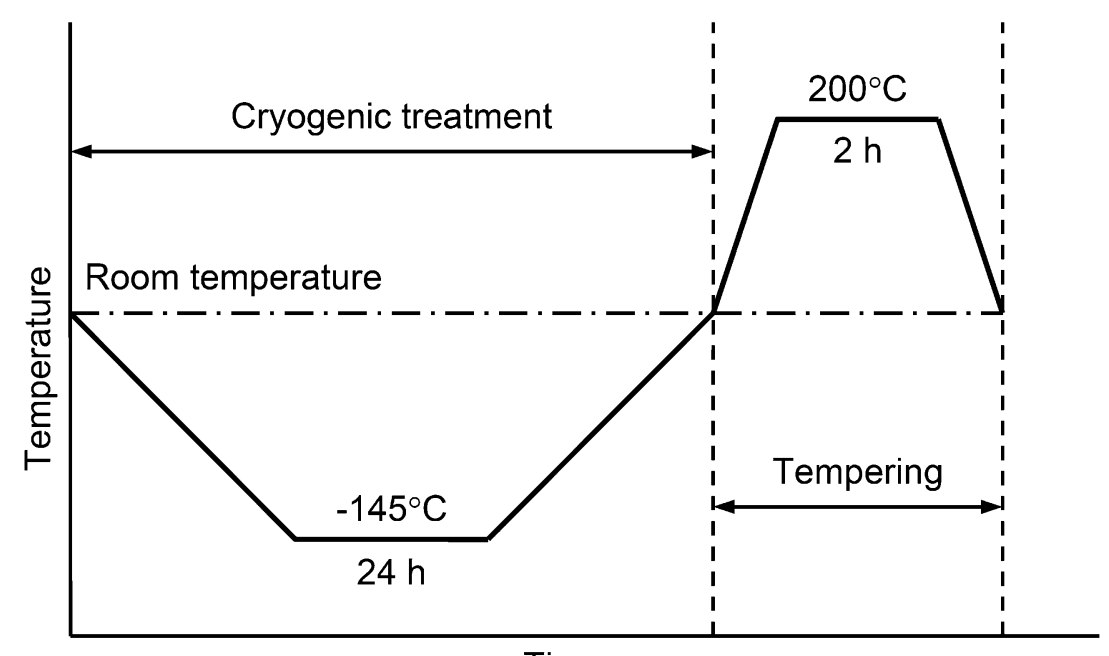

Time

Fig. 1. Schematic representation of the cryogenic and tempering treatment cycles followed in the study.

Table 1.

Experimental conditions

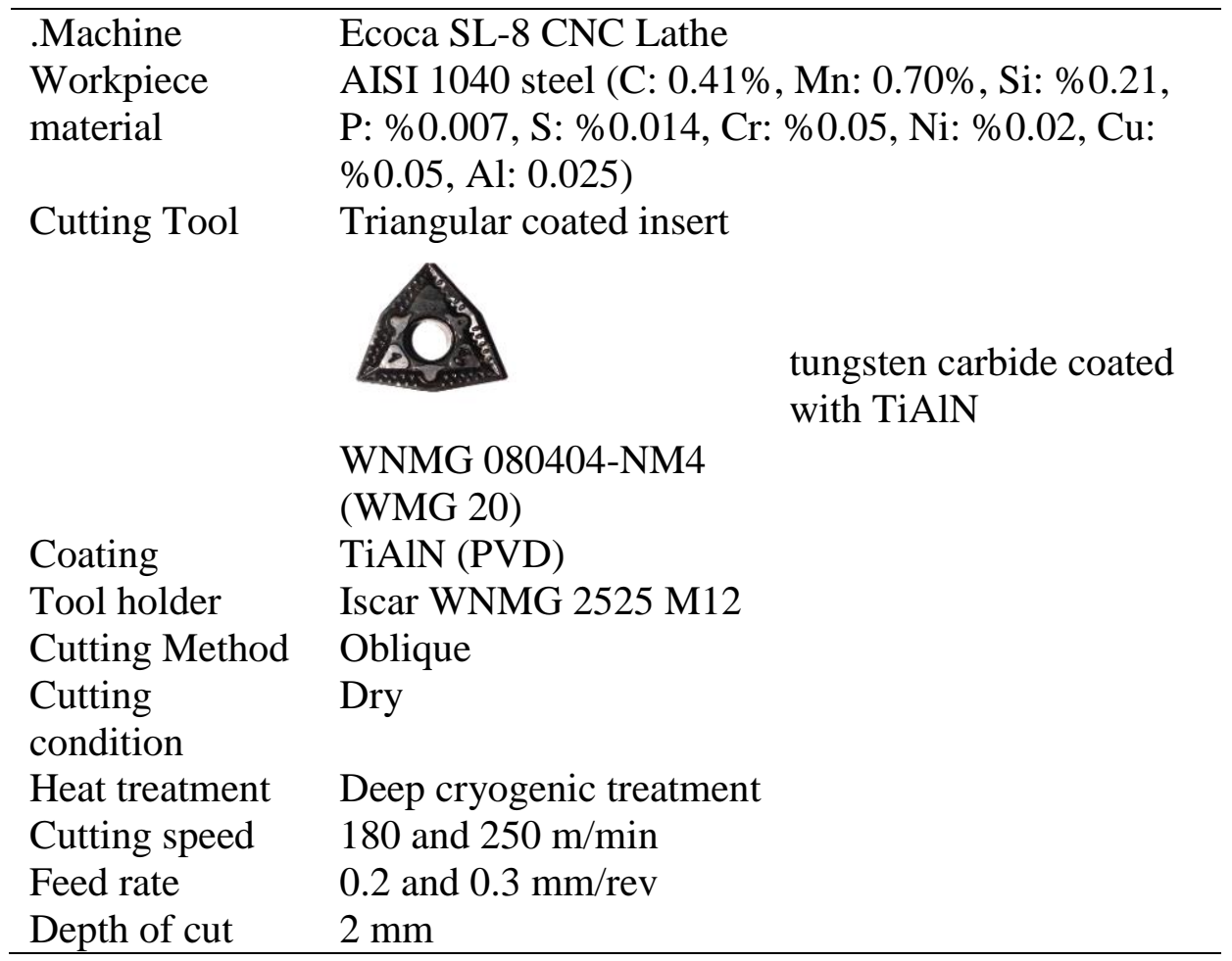




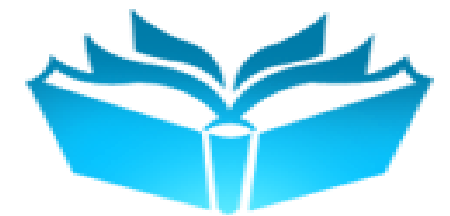 \\ I JRDET}

International Journal of Recent Development in Engineering and Technology

Website: www.ijrdet.com (ISSN 2347 - 6435 (Online) Volume 10, Issue 1, June 2021)

Manuscript Received: 12 Feb 2021, Received in Revised Form: 14 May 2021, Accepted: 20 June 2021 DOI: 10.54380/IJRDETV10I104

In the evaluation of surface roughness and wear properties, AISI 1040 steel is machined with cryogenic treated WC cutting tools at different feed rate and cutting speed. For wear performance, the work piece with $\phi 120 \times$ $250 \mathrm{~mm}$ was machined with WC cutting tools at a cutting depth $2 \mathrm{~mm}$, cutting speed $400 \mathrm{~mm} / \mathrm{min}$ and a feed rate of $0.25 \mathrm{~mm} /$ cycle. It was tried to determine the effect of cryogenic treatment on WC cutting toosl wear by calculating the machined volume of the material until the cutting tool is broken by the determined parameters. SEM images of the cutting tools were taken after wear tests to clearly see the erosion of the cutting tool.

\section{RESULTS AND DISCUSSION}

Surface Roughness is a measurable surface characteristic quantifying high frequency deviations from an ideal surface.
It is usually described by the arithmetic mean value $(\mathrm{Ra})$ based on the mean of the normal deviations from a nominal surface over a specified "cutoff" length and is given in following equation:

$$
R_{a}=\frac{1}{n} \sum_{i=1}^{n} y_{i}
$$

Where, ' $R_{a}$ ' is the surface roughness, ' $n$ ' is the number of measurement points and ' $y_{i}$ ' is the surface deviation at measurement point 'i.'. It is well known that the final geometry of surface roughness is influenced by various machining conditions such as spindle speed, feed rate and depth of cut. Feed rate is the rate at which the tool advances along its cutting path.

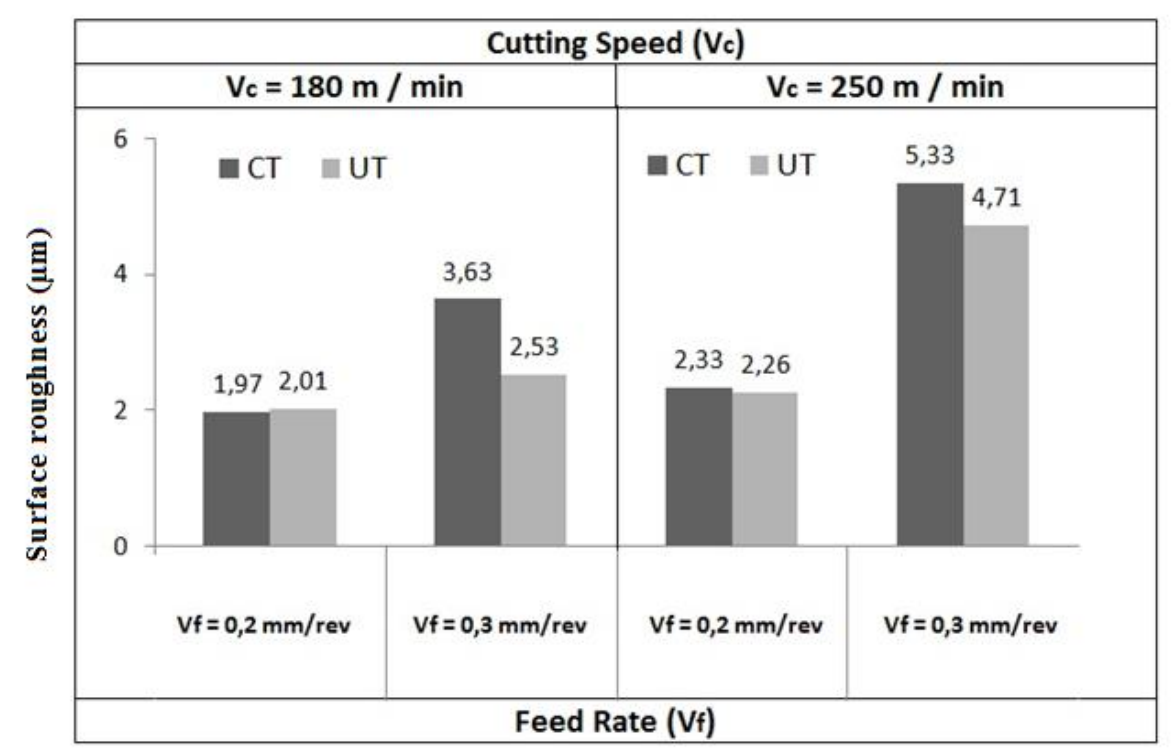

Fig. 2. Average surface roughness versus feed rate and cutting speed for the coated inserts.

In literature, Reddy et al. [15] showed that the roughness increases as a function of square of the feed rate flattening of ridges due to side flow or tool work relative vibrations. In addition to this, Abdullah et al. [16] realized that smaller feed rate and higher cutting speed can help to produce higher quality of surface. In contrast, depending on the increasing temperature with increasing cutting speed, deformation and chip flow are facilitated. Thus, surface roughness improves with increasing cutting speed [17]. In this study, the graphs of surface roughness as a function of feed rate and cutting speed is plotted for the CT and untreated (UT) cutting tools (Fig. 2).

The results regarding the effect of feed rate and cutting speed on the surface roughness obtained in this study is in agreement with the results of previous studies[18-23]. In addition, the surface roughness obtained from this study is close those of AISI 1015 steels coated with TiAlN and AlTiN using the PVD technique[24]. Fig. 2 shows that 


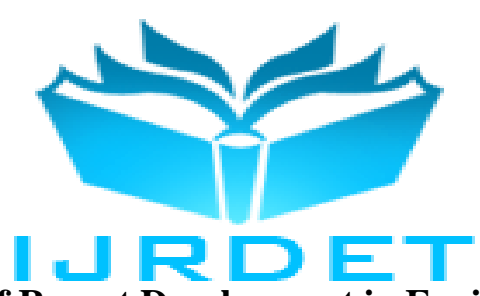

International Journal of Recent Development in Engineering and Technology

Website: www.ijrdet.com (ISSN 2347 - 6435 (Online) Volume 10, Issue 1, June 2021)

Manuscript Received: 12 Feb 2021, Received in Revised Form: 14 May 2021, Accepted: 20 June 2021 DOI: 10.54380/IJRDETV10I104

cutting conditions play an important role in surface roughness, and feed has a great influence on surface quality so increasing feed rate led to increase surface roughness also cutting speed the same effect in roughness which introduce tool wear.

This can be explained as follows; at high feed rate, a continuous chip formed which is increase of temperature in the workpiece and tool interface which is increase friction that leads to high roughness. On the other hand, we realize that the surface roughness of UT cutting tools appears to be somewhat better than CT cutting tools in the present study. To summarize, the feed rate was found out to be dominant factor on the surface roughness of tungsten carbide inserts coated with TiAlN. A good combination of cutting speed and feed rate can provide better surface qualities

Now let us consider the wear properties of CT and UT cutting tools. It is well known that wear characteristics have

(a)

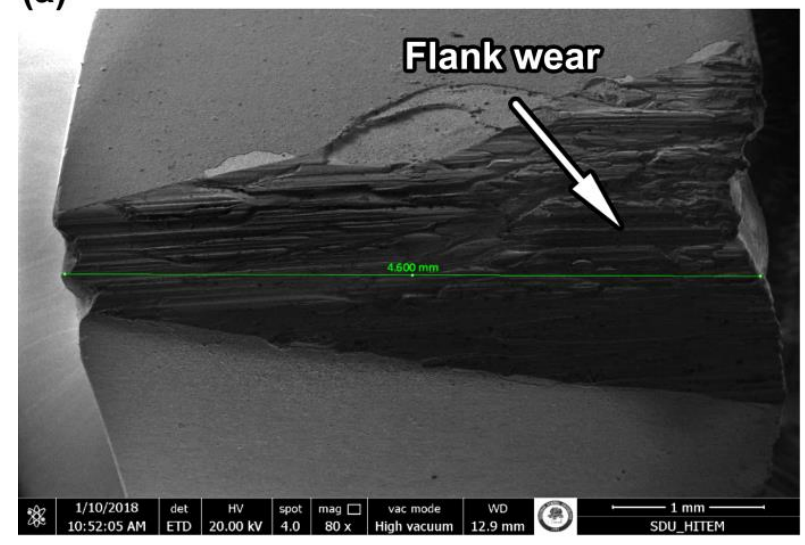

significant contribution to the enhancement of the material tool life.

For this purpose, the wear properties has been investigated under a constant feed rate and cutting speed ( $0.25 \mathrm{~mm} / \mathrm{rev}$ and $400 \mathrm{~m} / \mathrm{min}$.) for CT and UT cutting tools. Until the cutting tool breaks, the volumes of chips cut of the work pieces by CT and UT cutting tools are 47720 and $50240 \mathrm{~mm}^{3}$, respectively (Table 2). We saw that the CT and UT application produced a brittle region between the coated layer and the bulk workpiece of the cutting tools. So, wear was done quickly and the cutting tool was broken due to their microstructural features (Fig.3). For this reason, the volume of chips removed using CT cutting tools was less than that removed by UT cutting tools (Table 2).

Fig. 3. SEM images displaying flank wear on the coated inserts tested at a feed rate of $0.25 \mathrm{~mm} / \mathrm{rev}$ and cutting speed of $400 \mathrm{~m} / \mathrm{min}$.

Table 2.

Summary of total volume removed after wear testing.

\begin{tabular}{cc}
\hline Insert & Volume removed $\left(\mathrm{mm}^{3}\right)$ \\
\hline PVD-UT & 50240 \\
PVD-CT & 47720 \\
\hline
\end{tabular}

Contrary to the results obtained in our study, positive effects on improving the wear properties of materials by cryogenic treatment have been noticed in tool steels, carburized steels, cast irons and other materials. Corresponding to this, the treated inserts showed a better performance than the untreated ones of up to $34 \%, 53 \%$ and $29 \% 67 \%$ in flank wear and crater wear for tungsten [25] and cemented carbide inserts [26], respectively. This (b)

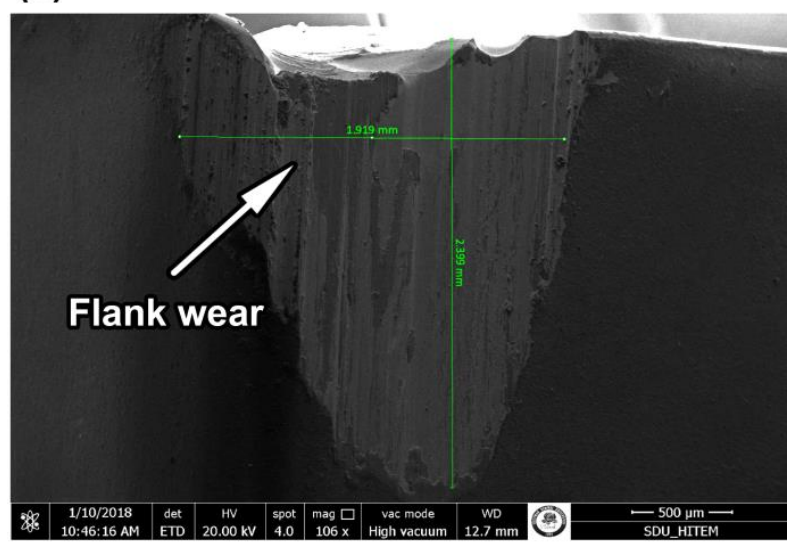

improvement has been explained by the increases in grain size and improved micro-structure of cemented carbide inserts. Similar results have also obtained in previous studies by Naravade et al. [27] and Jaswin et al. [28.

They showed that the cryogenic treatment improves the wear resistance and the hardness of the D6 tool steel and En 52 and 21-4N valve steels due to homogenized carbide distribution and formation of fine carbides dispersed in the 


\section{4 \\ JURDET \\ International Journal of Recent Development in Engineering and Technology Website: www.ijrdet.com (ISSN 2347 - 6435 (Online) Volume 10, Issue 1, June 2021)}

\section{Manuscript Received: 12 Feb 2021, Received in Revised Form: 14 May 2021, Accepted: 20 June 2021 DOI: 10.54380/IJRDETV10I104}

tempered martensite structure. These results show that the cryogenic treatment of tungsten carbide inserts improves tool life performance to a certain extent. In summary, the CT is a non-effective process to enhance the wear resistance of the WC cutting tools coating with PVD. This process decreases tool life and wear resistance of coated WC cutting tools.

\section{CONCLUSION}

Based on the results obtained in this study, the following conclusions can be drawn regarding the effect of CT on wear characteristic and surface roughness of WC cutting tools coated with TiAlN:

- The effect of feed rate and cutting speed is very high on the surface roughness. It may be concluded that better surface finish may be achieved at low feed rate and cutting speeds.

- WC cutting tools treated cryogenically showed the bad performance for the wear resistance and tool life.

- The CT could not produce a very fine carbides precipitation, and high volume fraction of the carbides due to the coating layer.

\section{REFERENCES}

[1] Production technology, Tata McGraw Hill Education Private Limited (2010), ISBN 13, pp. 1-60

[2] Stewart, H. A. 1998 Cryogenic treatment of tungsten carbide reduces tool wear when machining medium density fiberboard, Forest Prod. J. 54, 53-56.

[3] Bar-Hen, M and Etson, I. 2017 Experimental study of the effect of coating thickness and substrate roughness on tool wear during turning, Tribology International, 110, 341-347.

[4] Vereschaka, A. A., Grigoriev, S. N., Sitnikov, N. N, Oganyan, G. V. and Batako, A. D. L. 2017 A Working efficiency of cutting tools with multilayer nano-structured Ti-TiCN- $(\mathrm{Ti}, \mathrm{Al}) \mathrm{CN}$ and $\mathrm{Ti}-\mathrm{TiCN}$ ( $\mathrm{Ti}, \mathrm{Al}, \mathrm{Cr}) \mathrm{CN}$ coatings: Analysis of cutting properties, wear mechanism and diffusion processes, Surface and Coatings Technology, 332, 198-213.

[5] Kumar, S., Khedkar, N. K., Jagtap, B. and Singh, T. P. 2017 The Effects of Cryogenic Treatment on Cutting Tools, IOP Conf. Series: Materials Science and Engineering, 225, 012104.

[6] Slatter, T., Levis, R. and Jones, A. H. 2011 The influence of cryogenic processing on wear on the impact wear resistance of low carbon steel and lamellar graphite cast iron, Wear, 271, 1481-1489.

[7] Podgornik, B., Paulin, I, Zajec, B., Jacobson, S. and Leskovšek, V. 2016 Deep cryogenic treatment of tool steels, Journal of Materials Processing Technology, 229, 398-406.

[8] Pérez, M. and Belzunce, F. J. 2015 The effect of deep cryogenic treatments on the mechanical properties of an AISI H13 steel, Materials Science \& Engineering A, 624, 32-40.

[9] Li, J., Zhou, J., Xu, S., Sheng, J., Huang, S.,Sun, Y., Sun, Q. and Boateng, E. A. 2017 Effects of cryogenic treatment on mechanical properties and microstructures of IN718 super-alloy, Materials Science and Engineering A, 707, 612-619.

[10] P., Shao, G. Q, Duan, X. L, Shi, X. L., and Zhou, F. R. 2007 Low Temperature Synthesis of Tungsten Carbide by Embedment-Direct Reduction Carburization Process, Solid State Phenomena, 121-123, 171-174.

[11] Kalsi, N. S., Sehgal, R. and Sharma, V. S. 2014 Effect of tempering after cryogenic treatment of tungsten carbide-cobalt bounded inserts, Bulletin of Materials Science, 37, 327-335.

[12] Thakur, D., Ramamoorthy, B. and Vijayaraghavan, L. 2008 Influence of different post treatments on tungsten carbide-cobalt inserts, Materials Letters, 62, 4403-4406.

[13] Dhande, S. T., Kane, V. A., Dhobe, M. M. and Gogte, C. L. 2018 Influence of Soaking Periods in Cryogenic Treatment of Tungsten Carbide, Procedia Manufacturing 20,318-328

[14] Deshpande, R. G. 2015 Machining C-45 Steel With Cryogenically Treated and Microwave Irradiated Tungsten Carbide Cutting Tool Inserts, International Journal of Innovative Research in Science, Engineering and Technology, 4, 339-345.

[15] Reddy, M. R., Kumar, P. R. and Rao, G. K M. 2011 Effect of feed rate on the generation of surface roughness in turning, International Journal of Engineering Science and Technology, 3 , 8099-8105.

[16] Abdullah, A. B., Chia, L. Y. and Samad, Z. 2008 The effect of feed rate and cutting speed to surface roughness, Asian Journal of Scientific Research, 1, 12-21.

[17] Rezvani, E., Ghayour, H. and Kasiri, M. 2016 Effect of cutting speed parameters on the surface roughness of Al5083 due to recrystallization, Mech. Sci., 7, 85-91.

[18] Yalcin, B. 2015 Surface roughness and cutting forces in turning of tool steel with mixed ceramic and cubic boron nitride cutting tools, Transactions of the Canadian Society for Mechanical Engineering, 39, 323-336.

[19] Kumara, N. S., Shetty, A., Shetty, A., Ananth, K. and Shetty, H. 2012 Effect of spindle speed and feed rate on surface roughness of Carbon Steels in CNC turning, Procedia Engineering, 38, $691-697$.

[20] Ndaruhadi, P. Y. M. W., Sharif, S. and Kurniawan, D. 2015 Effect of Different Cutting Speed and Feed Rate on Surface Roughness in Femur Bone Drilling, Procedia Manufacturing, 2, 208-211.

[21] Yasir, M., Ginta, T. L., Ariwahjoedi, B., Alkali, A. U. and Danish, M. 2016 Effect of cutting speed and feed rate on surface roughness of AISI 316 SS using end milling, ARPN Journal of Engineering and Applied Sciences , 11, 2496- 2500.

[22] Abdullah, A. B., Chia, L. Y. and Samad, Z. 2008 The Effect of Feed Rate and Cutting Speed to Surface Roughness, Asian Journal of Scientific Research ,1, 12-21.

[23] Ibrahim, M. S., Sreedharan, T., Hadi, N. A. F, Mustapa, M. S., Ismail, E. A., Hassan, M. F. and Arifin, A. M. T. 2017 The Effect of Cutting Speed and Feed Rate on Surface Roughness and Tool Wear when Machining Machining D2 Steel, Materials Science Forum, 909, 80-85.

[24] Gokkaya, H. and Nalbant, M. 2006 The Effects of Cutting Tool Coating on the Surface Roughness of AISI 1015 Steel Depending on Cutting Parameters, Turkish J. Eng. Env. Sci. 30, 307 - 316.

[25] Ozbek, N. A., Cicek, A., Gulesin, M., and Ozbek, O. 2016 Effect of cutting conditions on wear performance of cryogenically treated tungsten carbide inserts in dry turning of stainless steel, Tribology International, 94, 223-233. 


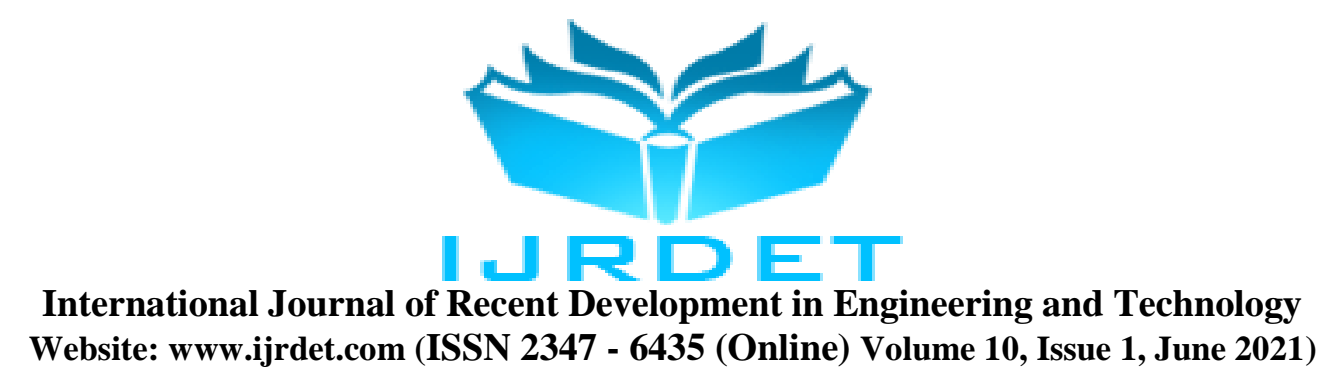

Manuscript Received: 12 Feb 2021, Received in Revised Form: 14 May 2021, Accepted: 20 June 2021 DOI: 10.54380/IJRDETV10I104

[26] Ozbek, N. A., Cicek, A., Gulesin, M., and Ozbek, O. 2014 Investigation of the effects of cryogenic treatment applied at different holding times to cemented carbide inserts on tool wear, International Journal of Machine Tools and Manufacture, 86, 34-43.

[27] Naravade, R. H., Gujar, U. N. and Kharde, R. R.2012 Optimization of Cryogenic Treatment on Wear Behaviour of D6 Tool Steel by Using DOE/RSM, International Journal of Engineering and Advanced Technology, 2, 239-244.

[28] Jaswin, M. A., Shankar, G. S. and Lal, D. M. 2010 Wear resistance enhancement in cryotreated En 52 and 21-4N valve steels, International Journal of Precision Engineering and Manufacturing, 11, 97-105.

[29] Péné, A.D., Barro, F.I., Kamta, M., Bitjoka, L., Nkeng, G.E., Kapseu, C.'Theoretical study of a bifacial silicon solar cell front side illuminated: Magnetic field effect on the recombination velocities inducing the short circuit and limiting the open circuit "(2021) International Journal of Emerging Technology and Advanced Engineering, 11 (2),

[30] Nwankwo, P.C. "An improved method for determining static bottom hole pressure in dry natural gas wells: A computer programming approach" (2020) International Journal of Emerging Technology and Advanced Engineering, 10 (5), pp. 171-175

[31] Tadesse, M., Giorgis, T.H. "Iternative energy resources potential of rift valley lakes basin of ethiopia: Potentials, challenges and future development perspective" (2020) International Journal of Emerging Technology and Advanced Engineering, 10 (2), pp. 1-18.

[32] Han, D.H."Convergence study on the use of electrolyzed water device with CNT cathode in health field" (2021) International Journal of Emerging Technology and Advanced Engineering, 11 (3), pp. 8-13.

[33] Rasheed, A.A., Wei, M., Mahapatra, R.N. "Exploring new paradigm for COVID-19 contact tracing through the eye of IoT: A blockchain approach"(2021) International Journal of Emerging Technology and Advanced Engineering, 11 (3), pp. 14-28.

[34] Alanazi, B.S., Rekab, K. "Fully sequential sampling design for estimating software reliability"(2020) International Journal of Emerging Technology and Advanced Engineering, 10 (7), pp. 84-91.

[35] Flesch, B.F., Tedeschi, I., De Figueiredo, R.M., Prade, L.R., Da Silva, M.R."A functional safety methodology based on IEC 61508 for critical reliability FPGA-based designs" (2020) International Journal of Emerging Technology and Advanced Engineering, 10 (7), pp. 12-19. 